Удк 005.591.6

\title{
ІННОВАЦІЙНИЙ АУТСОРСИНГ ЯК ІНСТРУМЕНТ УПРАВЛІННЯ ПІДПРИЄМСТВОМ
}

\section{INNOVATIVE OUTSOURCING AS A TOOL FOR ENTERPRISE MANAGEMENT}

\author{
Буняк Надія Михайлівна \\ кандидат економічних наук, доцент, \\ Волинський національний університет імені Лесі Українки \\ ORCID: https://orcid.org/0000-0001-6088-9081
}

\author{
Buniak Nadiia \\ Lesya Ukrainka Volyn National University
}

\begin{abstract}
У статті досліджено інноваційний аутсорсинг як інструмент управління підприємством. Виокремлено основні характеристики аутсорсингу та обґрунтовано доцільність його використання в інноваційній діяльності підприємства. Розкрито особливості інноваційного аутсорсингу. Визначено мотиви, які спонукають керівництво підприємства, що провадить інноваційну діяльність, до використання послуг аутсорсингових компаній. Окреслено стримуючі фрактори щодо передачі непрофільних бізнес-процесів стороннім організаціям. Обґрунтовано важливі передумови успішного залучення партнерів-аутсорсерів до здійснення інноваційного процесу. 3роблено висновок, що попри певні проблеми та ризики, інноваційний аутсорсинг є дієвим інструментом зміцнення ринкових позицій підприємства в умовах обмежених інноваційних можливостей.
\end{abstract}

Ключові слова: інновація, аутсорсинг, інноваційний аутсорсинг, інноваційний процес, аутсорсер.

В статье исследовано инновационный аутсорсинг как инструмент управления предприятием. Выделены основные характеристики аутсорсинга и обоснована целесообразность его использования в инновационной деятельности предприятия. Раскрыты особенности инновационного аутсорсингу. Определены мотивы, которые побуждают руководство предприятия, осуществляющего инновационную деятельность, к использованию услуг аутсорсинговых компаний. Выявлены сдерживающие фракторы по передаче непрофильных бизнес-процессов сторонним организациям. Обоснованно важные предпосылки успешного привлечения партнеров-аутсорсеров к осуществлению инновационного процесса. Сделан вывод, что несмотря на определенные проблемы и риски, инновационный аутсорсинг является действенным инструментом укрепления рыночных позиций предприятия в условиях ограниченных инновационных возможностей.

Ключевые слова: инновация, аутсорсинг, инновационный аутсорсинг, инновационный процесс, аутсорсер.

Changes in the business environment encourages enterprises to innovation activity in order to strengthen competitive position. At the same time, limited own resources necessitate the search for effective ways to optimize costs and improve performance. Under these circumstances, the role of outsourcing as a tool for enterprise management and activation of its innovation processes is growing. The purpose of the article is to develop the conceptual provisions of innovative outsourcing in the context of society's transition to an innovative development model. To achieve it, we used the methods of theoretical generalization, analysis and synthesis, as well comparative-critical analysis, system approach. The analysis of different author's approaches to the interpretation of the essence of the concept of "outsourcing" allowed determining its main characteristics. The expediency of outsourcing use in the innovative activity of the enterprise is substantiated. The defining motives that motivate the management of an enterprise to use the services of outsourcing companies are: lack of own scientific and technical potential and complexity of R\&D, lack of financial resources, risk allocation, cost reduction, reduction of the innovation cycle or its individual stages, the ability to quickly bring innovations to market. Innovative outsourcing due to its increased risk involves closer cooperation between the company and the outsourcing organization. A key tool for evaluating and managing the quality of outsourcing services is the service level agreement. In the conditions of transformation processes, the most expedient and economically justified is the gradual introduction of outsourcing in the practice of enterprises: the transfer of business processes should begin with less risky, non-core, and only then move to risky. Despite certain problems and risks, innovative outsourcing is an effective tool for strengthening the market position of the enterprise in conditions of limited innovation opportunities. The results of scientific research can be used for activation of innovation processes at the enterprise level.

Keywords: innovation, outsourcing, innovative outsourcing, innovation process, outsourcer. 
Постановка проблеми. Формування якісно нового інституційного середовища ведення бізнесу, загострення конкурентної боротьби за ринки збуту спонукають підприємства до провадження інноваційної діяльності задля зміцнення своїх ринкових позицій. Водночас обмеженість власних матеріальних та фрінансових ресурсів, нестача висококваліфрікованих спеціалістів обумовлюють необхідність пошуку ефективних способів оптимізації витрат та покращення результатів діяльності. За цих обставин зростає роль аутсорсингу як дієвого підходу до ведення бізнесу, який дає можливість зосередити увагу на виконанні основних процесів на підприємстві, зменшити кількість виконуваних функцій і тим самим підвищити ефеективність діяльності та віднайти додатковий потенціал для росту.

Конкурентоспроможність підприємства безпосередньо залежить від здатності його керівництва використовувати ефективні фрорми організації та управління інноваціями, а також приймати економічно обґрунтовані управлінські рішення щодо підвищення результативності інноваційної діяльності. Як свідчить досвід провідних компаній світу, багато з них досягнуло успіху на ринку завдяки залученню до процесу розробки, виробництва та комерціалізації інновацій сторонніх спеціалізованих компаній, тобто використання аутсорсингу.

Аналіз останніх досліджень і публікацій. Вагомий внесок у розроблення теоретичних і прикладних засад використання аутсорсингу зробили такі вітчизняні та закордонні науковці й практики, як О. М. Анісімова, Р. Р. Баглей, Т.В.Бучинська, Ю.В.Литюга, Г.О.Маркєєва, А. В. Панков, Н. В. Ревуцька, А. Г. Шатохіна та інші.

Незважаючи на наявність численних досліджень у сорері передачі непрофрільних фрункцій підприємства стороннім організаціям, проблемам використання аутсорсингу в інноваційній діяльності приділяється мало уваги. Це значно ускладнює розробку та впровадження дієвих заходів щодо активізації інноваційних процесів на мікрорівні. Недостатня теоретична розробленість зазначених вище питань обумовлює необхідність проведення подальших досліджень у цьому напрямі.

Формулювання завдання дослідження. Метою статті $€$ розробка концептуальних положень інноваційного аутсорсингу в умовах переходу суспільства до інноваційної моделі розвитку.

Виклад основного матеріалу дослідження. В умовах нестабільності більшості сорер діяльності, загострення конкурентної боротьби все більш широке застосування знаходить аутсорсинг як один з дієвих інструментів управління, який сприяє економічному й фрінансовому розвитку підприємства, нарощенню його конкурентних переваг шляхом проведення реструктуризації менеджменту та трансформації бізнес-процесів.

Термін «аутсорсинг» походить від англійського слова «outsourcing», яке $€$ скороченням словосполученням «outer source using», що в дослівному перекладі означає «використання зовнішніх ресурсів».

Виникнення практичного аутсорсингу пов'язують 3 іменами двох великих менеджерів - Г. Форда та А. Слоуна, які у процесі конкурентної боротьби між собою зрозуміли, що жодна компанія не може бути самодостатньою, а тому виконання окремих фрункцій доцільно передавати спеціалізованим фрірмам.

Активно розвиватись аутсорсинг почав у 60-х роках минулого століття у зв'язку з розвитком інформаційних систем та технологій, а також ускладненням умов ведення бізнесу, загостренням конкурентної боротьби, активним розвитком сорери послуг, поглибленням спеціалізації суб'єктів господарювання.

Історично аутсорсинг уперше був визнаний як бізнес-стратегія у 1989 році [1, с. 8], хоча його інструментарій використовувався ще задовго до цього. Сьогодні його можна розглядати як принципово нову концепцію управління бізнесом, яка передбачає передачу, як правило, непрофрільних бізнес-фрункцій спеціалізованим організаціям на засадах субпідряду за умови гарантування ними відповідного рівня їх виконання.

Аналіз різних авторських підходів [2; 3; 4] до трактування сутності поняття «аутсорсинг» дозволив виокремити основні його характеристики:

- наявність сторонньої компанії;

- передача непрофрільних фрункцій;

- глибока спеціалізація аутсорсингової компанії;

- оптимізація діяльності, зосередження зусиль на основних бізнес-процесах;

- налагодження й підтримка партнерських взаємовідносин;

- перерозподіл повноважень, відповідальності та ризиків;

- договірні основи взаємовідносин (наявність угоди про співпрацю).

Базова концепція аутсорсингу зводиться до трьох основних принципів: кожен повинен займатися своєю справою і мати можливість сконцентруватися тільки на ній; рішення супутніх завдань завжди можна доручити тому, хто справиться з ними краще; такий роз- 
поділ роботи заощаджує кошти замовника й приносить дохід виконавцю [2, с. 72].

Аутсорсинг дозволяє зменшити витрати, покращити якість товарів і послуг, вивільнити додаткові ресурси та зосередити їх на основному напрямі діяльності, отримати опосередкований доступ до ресурсів аутсорсингової компанії, поліпшити результати діяльності, диверсифрікувати ризики, підвищити ринкову вартість підприємства.

Заразом варто зазначити, що аутсорсингові відносини пов'язані 3 підвищеним ризиком, оскільки їхнє невиконання чи неналежне виконання може негативно позначитись на результатах діяльності замовника, а також спричинити погіршення його конкурентної позиції на ринку.

Прийняття рішення про використання аутсорсингу $€$ прерогативою вищого керівництва підприємства, оскільки безпосередньо пов'язане з його стратегічними інтересами та передбачає вибір між самостійним виконанням бізнес-срункцій та їх передачею стороннім організаціям. У цьому контексті надзвичайно важливими завданнями $€$ ґрунтовний аналіз всіх напрямів діяльності підприємства, оцінка їхньої ролі в забезпеченні досягнення основних стратегічних цілей, діагностика ризиків, визначення на цій основі переліку робіт, які доцільно передати аутсорсеру.

У теперішніх економічних реаліях відбувається розширення сорери застосування аутсорсингових послуг, що обумовлено насамперед стрімким розвитком інфрормаційно-комунікаційних технологій та активним впровадженням їх у всі ссрери життєдіяльності, прискоренням науково-технічних перетворень.

Зміна парадигми інноваційного розвитку суспільства, перехід від закритої до відкритої моделі інноваційного процесу, що передбачає активне використання зовнішніх джерел інноваційних ідей, посилення взаємозв'язків між окремими інноваційними циклами дозволяє зробити висновок, що підприємство може не здійснювати всі роботи в межах стадій інноваційного процесу (від НДДКР до ринкової комерціалізації інновації), а зосередити увагу лише на реалізації окремих з них. Тобто сьогодні немає ґрунтовних підстав стверджувати, що існує пряма кореляції між розробкою інновації, її матеріалізацією та комерціалізацією [3, с. 38].

Водночас обмеженість власних інноваційних можливостей та швидка зміна вподобань споживачів створюють об'єктивні передумови для становлення та розвитку інноваційного аутсорсингу як важливого інструменту зміцнення конкурентних позицій підприємства на ринку.
Литюга Ю. В. та Ревуцька Н. В. зазначають, що в контексті здійснення інноваційної діяльності «аутсорсингова модель бізнесу $€$ важливим джерелом генерування нових ідей, а також $є$ способом розвитку тих інновацій, які у даний момент не можуть бути реалізовані компанією самостійно» [5, с. 284].

Інноваційний аутсорсинг передбачає «передачу частини фуннцій, пов'язаних з розвитком інновацій, стороннім організаціям, тим самим знижує необхідність інвестування в підтримку вторинних функцій і в розвиток напрямів, які не забезпечують основну частку прибутку компанії» [4, с. 65].

Загалом його можна розглядати як бізнес-стратегію підприємства, згідно 3 якою керівництво підприємства передає частину срункцій з управління інноваціями стороннім організаціям.

Інноваційний аутсорсинг як інструмент управління підприємством, що провадить інноваційну діяльність, повинен насамперед:

- забезпечувати захист комерційної таємниці;

- сприяти скороченню тривалості інноваційного циклу;

- генерувати додатковий прибуток від провадження інноваційної діяльності;

- гарантувати економію витрат, пов'язаних 3 розробкою, виробництвом та комерціалізацією інновацій;

- передбачати використання нестандартних підходів до вирішення як рутинних, так і специфрічних завдань.

Інноваційний аутсорсинг пов'язаний, 3 одного боку, зі значними ризиками, а з другого - із суттєвими потенційними вигодами. Його практичне використання дозволяє розв'язати багато завдань, що стосуються ресурсного забезпечення інноваційної діяльності, скорочення тривалості інноваційного циклу (окремих його стадій), забезпечення раннього виведення інновації на ринок, збільшення рентабельності інвестицій тощо.

Згідно Панкова А.В., механізм аутсорсингу менеджменту інновацій може бути використаний на будь-якому етапі інноваційного процесу [6, с. 66].

Водночас, на нашу думку, найбільш виправданими 3 точки зору зміцнення конкурентної позиції підприємства на ринку є передача аутсорсинговим компаніям робіт, які передбачають насамперед генерацію інноваційних ідей, оцінку есрективності інноваційних проєктів, організаційну та технічну підготовку виробництва інновації, розробку заходів щодо виведення нових товарів та послуг на ринок. Тоді 
як за керівництвом підприємства має залишитися право прийняття рішення щодо того, які інноваційні проєкти доцільно реалізовувати, які винаходи виводити на ринку.

Визначальними мотивами, які спонукають керівництво підприємства, що провадить інноваційну діяльність, до використання послуг аутсорсингових компаній є: відсутність власного науково-технічного потенціалу та складність організації НДДКР, нестача фрінансових ресурсів, розподіл ризику, зменшення витрат, скорочення тривалості інноваційного циклу чи окремих його стадій, можливість оперативного виведення інновацій на ринок.

Заразом стримуючими фракторами щодо використання інноваційного аутсорсингу є:

- страх витоку інфрормації, що становить комерційну таємницю;

- недостатня інституційна підтримка;

- монопрофрільність аутсорсерів, що обумовлює необхідність залучення до виконання окремих фрункцій субаутсорсерів;

- складність прийняття комплексних і синхронізованих рішень щодо різнорідних технікотехнологічних і організаційно-управлінських аспектів реалізації інноваційного проєкту;

- висока невизначеність, неможливість остаточно передбачити кінцевий результат виконання роботи;

- складність контролю за діяльністю аутсорсера.

Додатковими перешкодами на шляху розвитку інноваційного аутсорсингу в Україні $є$ : «вузькі місця» законодавчої бази та правового регулювання, нерозвинена інфрраструктура підтримки інноваційної діяльності, відсутність стратегічного бачення у більшості суб'єктів господарювання, недовіра до аутсорсингових компаній.

На нашу думку, важливими передумовами успішного використання інноваційного аутсорсингу є:

- забезпечення балансу між функціями, які підприємство виконує самостійно, і тими, які передає аутсорсеру;

- узгодження та юридичне врегулювання всіх спірних питань щодо розподілу авторських прав на інноваційні рішення та прибутку від реалізації інноваційного проєкту;

- постійний моніторинг за виконанням аутсорсингового договору, розробка гнучкої та зручної для підприємства-замовника системи звітності, що дозволяє останньому контролювати процес виконання переданих функцій тією мірою, яка необхідна;

- вдалий вибір партнера - аутсорсингової компанії;
- забезпечення належного захисту інтелектуальної власності;

- обґрунтування системи вимог до якості виконання функцій, переданих аутсорсинговій компанії;

- створення команди, що буде безпосередньо співпрацювати з аутсорсером;

- забезпечення належного обміну інорормацією між внутрішніми та зовнішніми командами.

3 огляду на підвищену ризиковість інноваційний аутсорсинг передбачає більш тісну співпрацю між підприємством та аутсорсером. При виборі якого необхідно насамперед керуватись такими критеріями, як: репутація на ринку; тривалість функціонування; рівень володіння ключовими компетенціями; наявність практичного досвіду в певній сорері; розмір бізнесу й фрінансова стабільність; якість та вартість послуг; надійність обслуговування; місце розташування; технічні можливості; наявність системи передачі знань. При цьому пріоритет варто віддавати якісним показникам над кількісними.

Сам процес прийняття рішення про використання інноваційного аутсорсингу повинен охоплювати такі етапи:

- стратегічна оцінка поточного стану підприємства, вивчення власних інноваційних можливостей;

- прийняття рішення про передачу окремих фрункцій аутсорсеру;

- аналіз сильних та слабких сторін аутсорсингових компаній та вибір партнера;

- переговори про співпрацю, детальне обговорення всіх вимог та спірних питань, розробка умов договору;

- налагодження прозорих партнерських відносин, перехід на новий фрормат взаємовідносин;

- контроль за виконанням робіт, переданих на виконання аутсорсинговим компаніям; прийняття на основі його результатів рішення про продовження, припинення контракту чи внесення до нього відповідних коректив.

Ключовим інструментом оцінки та управління якістю послуг аутсорсингу є угода про рівень сервісу (SLA - Service Level Agreement), яка регламентує всі основні аспекти взаємовідносин замовника та постачальника послуг. Крім того, вона не лише окреслює спектр послуг, але й надає замовнику необхідний рівень захисту на випадок, якщо визначені в договорі умови не були виконані.

У зв'язку з тим, що аутсорсингові організації, як правило, є вузькоспеціалізованими і не можуть забезпечити комплексну підтримку інноваційного проєкту підприємство змушене 
укладати кілька аутсорсингових контрактів 3 різними компаніями.

В умовах трансорормаційних процесів найбільш доцільним та економічно виправданим $\epsilon$ поступове впровадження аутсорсингу в практику діяльності підприємств, тобто передачу бізнес-процесів слід починати 3 менш ризикованих, непрофрільних, і лише згодом переходити до ризикових.

Висновки. Отже, проведене дослідження відображає результати узагальнення наукових здобутків українських та зарубіжних вчених й фахівців-практиків у сорері становлення та розвитку інноваційного аутсорсингу.

Використання різних загальнонаукових та спеціальних методів дослідження дозволило зробити висновок, що застосовування сучасних інструментів управління, зокрема аутсор- сингу, дозволяє підприємству не лише підвищити свою адаптивність до умов зовнішнього середовища, але й значно покращити результати діяльності, зміцнити конкурентні переваги на ринку.

Керівництво підприємства повинно чітко розуміти: які вигоди воно може отримати (зокрема, швидкість та якість послуг) і на яких стадіях інноваційного процесу найбільш доцільним є залучення аутсорсингових компаній.

Попри певні проблеми та ризики, інноваційний аутсорсинг є дієвим інструментом зміцнення ринкових позицій підприємства в умовах обмежених інноваційних можливостей.

Перспективи подальших досліджень полягають в обґрунтуванні системи показників оцінки еорективності взаємодії між підприємством-замовником та аутсорсером.

\section{СПИСОК ВИКОРИСТАНИХ ДЖЕРЕЛ:}

1. Баглей Р. Р., Бучинська Т. В. Аналіз трансформації світового ринку праці під впливом революції 4.0. Інноваційна економіка. 2019. № 1-2 (78). С. 5-12.

2. Маркеева Г. А. Аутсорсинг в системе международного разделения труда. Модели, системы, сети в экономике, технике, природе и обществе. 2012. № 1(2). С. 71-74.

3. Шатохина А. Г. Аутсорсинг и его роль в инновационном развитии предприятия. Известия Тульского государственного университета. 2013. № 4-1. С. 38-43.

4. Анисимова О. Н. Инновационный аутсорсинг и его преимущества на предприятиях строительной отрасли. Теоретичні і практичні аспекти економіки та інтелектуальної власності. 2013. Вип. 1. Т. 3. С. $283-286$.

5. Литюга Ю. В., Ревуцька Н. В. Ризики інноваційної діяльності та сучасні аутсорсингові моделі її здійснення. Стратегія економічного розвитку України. 2012. № 30. С. 61-67.

6. Панков А. В. Аутсорсинг фрункцій менеджменту інновацій на базі субрегіонального інноваційного ринку. Економіка: реалії часу. 2012. № 3-4 (4-5). С. 63-66. URL: http://economics.opu.ua/files/archive/2012/n4-5.html (дата звернення: 20.05.2021).

\section{REFERENCES:}

1. Bahlei, R. R., Buchynska, T. V. (2019) Analiz transformatsii svitovoho rynku pratsi pid vplyvom revoliutsii 4.0 [Analysis of the transformation of the world labour market under the influence of revolution 4.0]. Innovatsiina ekonomika - Innovative economy, no. 1-2 (78), pp. 5-12. (in Ukrainian)

2. Markeeva, G. A. (2012) Autsorsing v sisteme mezhdunarodnogo razdeleniya truda [Outsourcing in the international division of labor]. Modeli, sistemy, seti v ekonomike, tekhnike, prirode i obshchestve - Models, systems, networks in economics, engineering, nature and society, no. 1(2), pp. 71-74. (in Russian)

3. Shatokhina, A. G. (2013) Autsorsing i ego rol' v innovatsionnom razvitii predpriyatiya [Outsourcing and its role in innovative development of industrial enterprise]. Izvestiya Tul'skogo gosudarstvennogo universiteta - Izvestiya Tula State University, no. 4-1, pp. 38-43. (in Russian)

4. Anisimova, O.N. (2013) Innovatsionnyy autsorsing i ego preimushchestva na predpriyatiyakh stroitel'noy otrasli [Innovative outsourcing and its benefits to the enterprises of the construction industry]. Teoretychni $i$ praktychni aspekty ekonomiky ta intelektualnoi vlasnosti - Theoretical and Practical Aspects of Economics and Intellectual Property, no. 1, vol. 3, pp. 283-286. (in Russian)

5. Lytiuha, Yu. V., Revutska, N. V. (2012) Ryzyky innovatsiinoi diialnosti ta suchasni autsorsynhovi modeli yii zdiisnennia [Risks of innovation and modern outsourcing models of its implementation]. Stratehiia ekonomichnoho rozvytku Ukrainy - Strategy of economic development of Ukraine, no. 30, pp. 61-67. (in Ukrainian)

6. Pankov, A. V. (2012) Autsorsynh funktsii menedzhmentu innovatsii na bazi subrehionalnoho innovatsiinoho rynku [Outsourcing of innovative management functions to the subregional innovative market]. Ekonomika: realii chasu - Economics: time realities, no. 3-4 (4-5), pp. 63-66. Available at: http://economics.opu.ua/files/archive/2012/ n4-5.html (accessed 20 May 2021). 